\title{
X-Ray mapping in heterocyclic design. X-Ray diffraction study of the derivatives 5-amide-4,6-dimethylpyridone-2
}

E.M. Feklicheva $(\mathrm{Okul})^{1}$, $\underline{\text { A.A. Kononenko }}^{2}$, E.V. Babaev ${ }^{1}$, V.B. Rybakov ${ }^{1}$

${ }^{1}$ M.V. Lomonosov Moscow State University, Chemistry Department, Vorob'evy Gory, 1-3, 119991, Moscow, Russia.

${ }^{2}$ Gubkin Russian State University of Oil and Gas (National Research University), Leninsky Prospect, 65-1, 119991, Moscow, Russia.

\section{E-mail: anjakononenko1994@gmail.com}

Crystal and molecular structures of 9 target (1-7) and 2 incidental (8a, 8b) compounds were studied by single crystal X-Ray analysis. All samples were characterized by ${ }^{1} \mathrm{H}$ NMR spectra. A comparative analysis is performed for bond lengths, bond and torsion angles with similar fragments of the parent molecules. In many structures the H-bonds were localized that influence the strength of molecular packing in crystals. Different rotation angles of amide group from the pyridine heterocycle were registered in the polymorph crystals of compounds $\mathbf{1}$ and $\mathbf{2}$. Chemical problems of preparation and full description of studied molecular and crystal structures will be discussed.

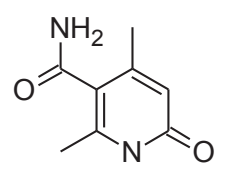

(1)

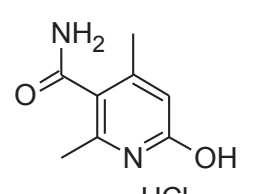

(1a)

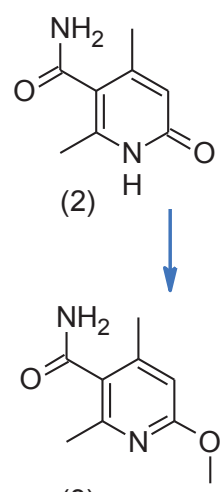

(3)

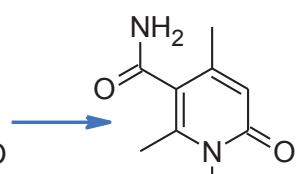<smiles>CC(=O)CN</smiles><smiles>Cc1cc(O)nc(C)c1C(N)=O</smiles>

$(5 a, b)$<smiles>[R]c1ccc(C(=O)CC)cc1</smiles><smiles>[R]c1ccc(C(=O)CCC(=O)c2ccc(Br)cc2)cc1</smiles>

a) $\mathrm{R}=\mathrm{Me}$

b) $\mathrm{R}=\mathrm{Cl}$<smiles>[R]c1ccc(-c2cc3c(C(N)=O)c(C)cc(N4CCOCC4)n3c2)cc1</smiles><smiles>[R]c1ccc(-c2c[n+]3c(C)c(C(N)=O)c(C)cc3o2)cc1</smiles>

(6b) (7b)

Keywords: molecular structure, heterocycles, pyridone-2, indolizine 